\title{
VERB SECOND IN AFRIKAANS: IS THIS A UNITARY PHENOMENON? ${ }^{1}$
}

\author{
Theresa Biberauer \\ Department of Linguistics, University of Cambridge
}

\section{Introduction}

The Verb Second (V2) phenomenon is a syntactic characteristic which features, to a greater or lesser extent, in all the Germanic languages. What it entails is the obligatory occurrence of finite verbs (Vfs) in clause-second position, following some initial (usually phrasal ${ }^{2}$ ) constituent. The nature of the initial phrasal constituent is not restricted in any way, with subjects, objects, adverbials, negative phrases, and wh-phrases all qualifying as potential first position elements (see examples (1) - (5) below):

1. André het gister die storie geskryf

André has yesterday the story written

2. Gister het André die storie geskryf

Yesterday has André the story written

3. Die storie het André gister geskyrf

The story has André yesterday written

4. Nêrens praat mense meer Latyn nie

Nowhere speak people more Latin

5. Wat lees jy vandag?

What read you today 
The V2 phenomenon has received a lot of attention in the syntactic literature in general and in the literature on Germanic syntax and specific Germanic languages in particular ${ }^{3}$. One Germanic language which has, however, never received more than a passing reference in these discussions is Afrikaans. The primary reason for this is that the V2 characteristics of its parent, Dutch, are well known, while the syntax of Afrikaans has been said to diverge very little from that of its parent (see inter alia Scholtz 1980: 91, Raidt 1983: 173, and Pheiffer 1989: 88). Moreover, most generative syntactic work that has been done on Afrikaans to date has focused on the standard (i.e. written) language which does indeed mirror Dutch syntax to a large extent ${ }^{4}$.

The purpose of this paper is to show that Afrikaans - and especially the modern spoken standard variety (henceforth MSA = "modern spoken Afrikaans") - does indeed merit separate attention within the context of V2 research. Specifically, it will be shown that a change which is currently affecting V2 in MSA and which is already starting to influence the perceived acceptability of V2 structures in standard Afrikaans (henceforth $\mathrm{AB}=$ "Algemeen Beskaafde

[i.e. standard] Afrikaans") is of a particularly interesting kind, and may point to the importance of factors which have, to date, been neglected within the context of V2 research.

To situate the discussion of Afrikaans V2, the relevant background is presented in section 2 . An outline of the V2 characteristics of standard Afrikaans follows in section 3, whereafter section 4 focuses on the MSA V2 facts: distributional findings are presented and the differences between MSA and AB V2 patterns highlighted. Section 5 introduces the proposed analysis of the $\mathrm{AB}$ and MSA facts, and section 6 provides a concluding summary.

\section{Background information}

\subsection{Afrikaans and the Minimalist Program}

As far as this paper is concerned, the most noteworthy characteristic of Afrikaans is its extreme morphological impoverishment. As has been noted in the literature ${ }^{5}$, Afrikaans has lost most of the inflectional system that characterises standard Dutch. Today, the only remaining instances of overt inflection are the prefix ge-denoting the past (and, syncretically, 
the passive) participle, and the distinct present, past and future tense forms manifested by the auxiliary wees ("be") and the lexical verb hê ("have"). These verbs do not reflect any person, gender or number agreement, a fact which means that Afrikaans auxiliaries exhibit even less inflection than their English counterparts. Consider Table 1 below.

Table 1: Inflecting verbs in Afrikaans

\begin{tabular}{|l|l|l|}
\hline & wees - "to be" & hê - "to have/own" \\
\hline Infinitive/Imperative & wees & hê/het \\
\hline Present Tense & is & het \\
\hline Past Tense & was & het \\
\hline Past Participle & gewees & gehad \\
\hline
\end{tabular}

Seen from the perspective of Chomsky's (1995 and 1998) morphologically driven Minimalist Program, Afrikaans's extreme deflection would be expected to result in English-style absence of pre-Spellout movement. The various proposals that have been made regarding the correlation between overt morphology and syntactic movement in Germanic ${ }^{7}$ have, as Bobalijk (1995: 44) expresses it, without exception "been derailed by Afrikaans, or make exactly the wrong predictions about it". Syntactically, Afrikaans behaves like a richly inflected language, even though it is the most poorly inflected of all the Germanic languages. Clearly, then, Afrikaans presents a rather thorny empirical challenge within the context of Minimalist theorising. The developments which will be discussed in this paper further underline the futility of postulating overt morphological triggers to account for observable movement: the apparent extension of $\mathrm{AB}$ 's verb-raising possibilities strongly suggests that, far from being mere fossilised relics of an earlier morphologically richer (Dutch) period, its synchronic movement characteristics follow from independent considerations. These will not be considered at any length here, but Biberauer (2001) contains a detailed discussion of this matter.

\subsection{The traditional analysis of $\mathrm{V} 2$ and the issue of SOV V2 languages}

Since (Koster 1975) and (Den Besten 1977/1983), V2 has been analysed as a phenomenon which is derived via two obligatory movements, namely 
(a) movement of the finite verb to $\mathrm{C}$ position, and

(b) movement of some phrasal (XP) category to Spec-CP.

Evidence from inter alia the complementary distribution of V2 and overt complementisers in Dutch and German, complementiser agreement languages ${ }^{8}$ and conditional alternation ${ }^{9}$ support this V-to-C theory which has become known as the Classical Theory. In terms of the Classical Theory, therefore, V2 necessarily involves the finite verb (Vf) being located in C. One would, therefore, not expect to find V2 co-occurring with the presence of an overt complementiser (see section 2.3 below). Alternative analyses have been proposed to deal with the problematic cases in which V2 and overt complementisers do co-occur (see inter alia Diesing 1990, Rögnvaldsson and Thráinsson 1990, Santorini 1994, and Vikner 1995), but these will not concern us here. For the purposes of this paper, "genuine V2" is to be interpreted straightforwardly in the classical sense as "Vf-in-C".

Also since (Koster 1975), those V2 languages which display a so-called "matrix-embedded asymmetry" - i.e. V2 in matrix clauses (MCs) and V-final order in embedded clauses (ECs) have standardly been analysed as underlyingly $\mathrm{SOV}^{10}$. In terms of Koster-style analyses, the EC word order of Continental (i.e. West) Germanic languages is, therefore, somewhat counterintuitively, assumed to be primary and the $\mathrm{MC}$ order derived ${ }^{11}$. By virtue of the fact that Afrikaans exhibits the same matrix-embedded asymmetry as its parent, it was typically analysed as an SOV language during the 70s and 80s (see inter alia Waher 1982 and Oosthuizen 1985). Following the appearance of Zwart's (1993 and 1994) alternative SVO proposal for Dutch - and, by extension, all the traditional SOV languages - SVO analyses of Afrikaans have also been proposed (see inter alia, Oosthuizen 1994, 1996, and 1998; Vriends 1998; and Conradie 1999). The proposal that Afrikaans conforms to Kayne's (1994) Universal Base Hypothesis - being underlyingly SVO and exhibiting SOV ordering in ECs as a consequence of feature-driven movement - is also adopted in this paper. Specifically, the (Minimalist) clause structure that is proposed for Afrikaans is illustrated in Figure 1: 
Figure 1: The clause structure of Afrikaans

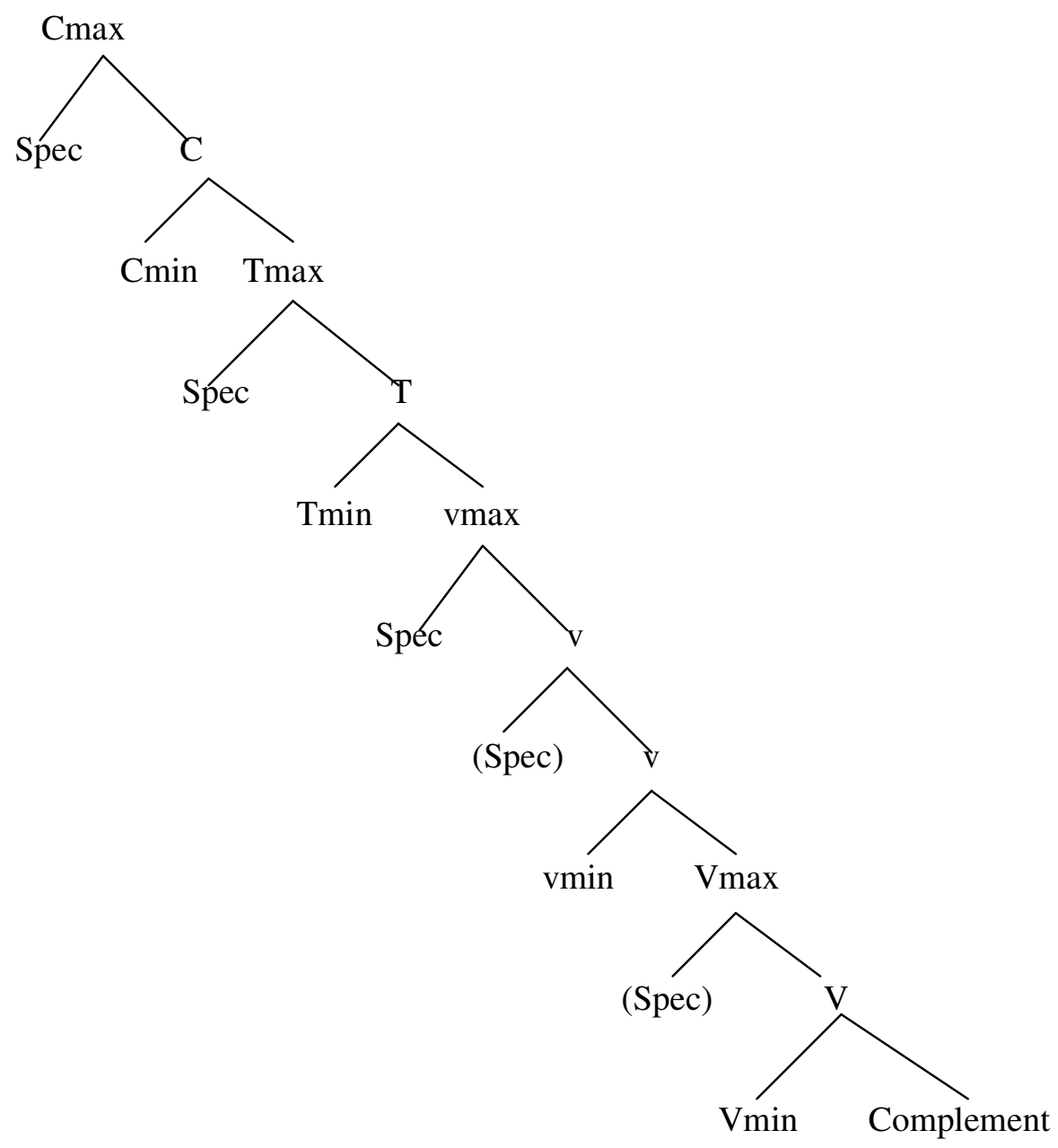

In terms of this proposed structure, Afrikaans's characteristic V2 and V-final orderings are derived as follows:

(a) Lexical verbs are base-generated under Vmin and always raise to at least vmin, the "light" v position in Larson's (1988) seminal VP-shell analysis which was subsequently adopted by Hale and Keyser (1993) and Chomsky (1995). "Light" v is, therefore, viewed as a hybrid category, relating crucially to the presence of an external argument and the possibility of Accusative Case assignment - see Burzio's Generalisation (1986: 178ff). Raising-to-v facilitates the possibility of the multiple v-related specifiers 
discussed in (b) and (c) below (see Chomsky's 1995 Minimal Link Condition and the contributions in Adger et al. 1999).

(b) Internal arguments (both nominal and clausal) are merged under V-Complement and subsequently raise to inner Spec- ${ }^{12}$ under the influence of the strong D-feature on Spec-v. In the case of nominal arguments, this raising is generally associated with Accusative Case checking, these Case features being "free riders" in the sense of Chomsky $(1995)^{13}$.

(c) External arguments are merged under outer Spec-v, therefore, the VP-Internal Subject position is Spec-v in this analysis, Spec-V representing a position which is available to the non-theme argument selected by ditransitive verbs - (see Larson 1988 and subsequent work).

(d) The V-feature on $\mathrm{T}$ is weak ${ }^{14}$; therefore, $\mathrm{V}$-to-T raising does not take place in either $\mathrm{MCs}$ or $\mathrm{ECs}^{15}$.

(e) The entire vP - the first "phase" in Chomsky's (1999) sense - raises to Spec-T in order to identify Spec-T via the typically Germanic SOV Spec-T identification mechanism proposed in Biberauer (2001) ${ }^{16}$. In view of the fact that the $\mathrm{V}$-feature on $\mathrm{T}$ is assumed to be weak on this analysis, the lexical verb does not enter into the scope of the tense features hosted in $\mathrm{T}$ via overt $\mathrm{V}$-to-T raising of the kind that operates in the Romance languages (see Pollock 1989). Presumably, the purpose of V-to-T (and also T-to-C) raising is, as Chomsky (1999: 31) proposes, to create (possibly universal) LFinterpretable "supercategories" or verbal complexes unifying all the verbal meaning in a given clause. In the absence of V-to-T movement and, crucially, in the simultaneous absence of the traditional subject-requiring EPP requirement, vP-raising functions to facilitate the creation of the agreement-expressing V-T complex. Since Vf is vP-final following the raising of the internal and external arguments to inner and outer Spec-v respectively, the raising of the $\mathrm{vP}$ phase to Spec-TP brings about the characteristic EC V-final ordering. The proposal is, therefore, that Afrikaans declarative ECs are TPs. 
(f) In the case of MCs, Vf raises further to $\mathrm{C}$ under the influence of some V2 trigger (the precise nature of which is not examined here ${ }^{17}$ ).

(g) Some XP then raises to Spec-CP, thereby deriving the MC V2 ordering. Afrikaans declarative MCs are, therefore, CPs.

Crucially, then, the proposed analysis of Afrikaans MCs and ECs presupposes that these clauses are "different sizes": MC declaratives are CPs, while EC declaratives are TPs ${ }^{18}$.

\subsection{The Typology of $\mathrm{V} 2$ languages}

Taking the Classical V-in-C analysis of V2 as his point of departure, Vikner (1995: 65ff) has proposed a typology of V2 languages According to Vikner, the following kinds of V2 languages can be distinguished:

(a) Residual V2 languages: These only exhibit V2 in a very narrowly constrained set of circumstances, specifically those involving first position elements associated with interpretable features. Of the Germanic languages, English is the only such V2 language with V2 - usually designated subject-auxiliary inversion - occurring almost exclusively in $w h$-questions, negative inversion and comparative inversion contexts ${ }^{19}$.

(b) "Well behaved" V2 languages: One of the so-called full V2 languages, these present V2 constructions in all MC environments and, additionally, in ECs which lack overt complementisers. German and Dutch are languages which exhibit this kind of V2.

(c) Limited embedded V2 languages: These full V2 languages exhibit all the same matrix and embedded V2 patterns as the "well behaved" V2 languages and, additionally, allow embedded V2 in the sentential complements of an ill-defined, but obviously restricted class of matrix verbs commonly known as bridge verbs. Faroese ${ }^{20}$, Danish, Norwegian and Swedish are all said to belong to this group of V2 languages. 
(d) General embedded V2 languages: These full V2 languages display all the matrix and embedded V2 options permitted in limited embedded V2 languages, but the range of matrix verbs allowing embedded V2 is not subject to any restriction; the bridge verb conundrum, therefore, does not arise. Yiddish and Icelandic are the two languages which have been identified as general embedded V2 languages.

One of the central problems facing Vikner's typology is the vagueness surrounding the precise definition of the notion 'bridge verb'. The term "bridge verb" originally designated verbs which permit complementiser deletion - e.g. André said (that) he had written an article on the Olympics - and extraction from their sentential complement - e.g. What article did André say that he had written ? $^{21}$. As Vikner (1995: 70) himself notes, however, the class of verbs permitting embedded V2 in the extraction-tolerant Mainland Scandinavian languages is much smaller than the class allowing extraction. Reference to bridge verbs in V2 literature cannot, therefore, straightforwardly be taken to refer to the original class of extractionpermitting verbs. Similarly, it has been pointed out by non-Germanic linguists that the class of verbs triggering V2 in Germanic embedded contexts cannot be identified with the class exhibiting complementiser deletion phenomena in languages like Italian (see inter alia Giorgi and Pianesi 1997: 236ff). To complicate matters further, it has also proved impossible to identify an independently valid list of verbs which permit embedded V2 in embedded V2 languages (i.e. (c) and (d) in Vikner's typology; see the attempts by Grewendorf 1988: 82; Haider 1986: 53; Helbig and Buscha 1986: 646-647; and Reinholtz 1989: 104, fn. 4).

\subsection{Data}

The findings presented below are based on two types of data, namely

(a) native-speaker grammaticality judgements, and

(b) corpus data drawn from three newly collected corpora of data.

The initial motivation for the investigation came from our observation that the spoken V2 production of native Afrikaans speakers did not always conform to the prescriptive stipulations of the standard. Broadly speaking, it was observed that native-speakers employ 
various kinds of embedded V2 that are not permitted in standard Afrikaans ${ }^{22}$. In the first instance, we wished to ascertain which kinds of non-standard embedded V2 native-speakers were prepared to accept. To this end, appropriate instances of embedded V2 constructions were recorded - both in isolation, without contextual embedding, and embedded in suitable linguistic contexts. Fifteen native-speakers - all of whom had a minimum of 3 years' tertiary education and none of whom spoke markedly regional varieties of Afrikaans - were then tested as to the acceptability of the constructions. Based on the judgements obtained in this way, an initial profile was drawn up of the change that was putatively underway (see section 4 below). Three Afrikaans corpora of roughly 80000 words each were then collected in order to investigate actual V2 distribution in:

(a) early Afrikaans, i.e. Afrikaans as it was just before it was standardised, when it was still, to all intents and purposes, a spoken language ${ }^{23}$. The reason for considering a corpus of this nature was to control whether non-standard embedded V2 had occurred in earlier spoken Afrikaans. If this were found to be the case, the possibility that the embedded V2 structures currently present in spoken Afrikaans merely reflect the persistence of a register- or modality-specific feature, rather than a genuine innovation, would clearly become a consideration. The early Afrikaans data were drawn from letters, diaries, newspaper columns, and novel extracts dating from 1887 - 1923;

(b) modern written Afrikaans, i.e. Afrikaans which gives an indication of the state of the standard as modern-day users perceive it. The modern written data were drawn from a variety of newspapers and magazines; and

(c) modern spoken Afrikaans, i.e. Afrikaans which gives an indication of where, how, and by how much the spoken form currently deviates from the standard. The data for this corpus was drawn from radio, television and other interviews. In all cases, only speakers who did not speak strongly regional varieties of Afrikaans were considered. Speakers who code-switched to such an extent that extended sections of their contributions were actually in English and those who were evidently very nervous in their delivery were also excluded. The reason for this is that the ultimate goal is to 
obtain as realistic a picture as possible of the kind of Afrikaans speakers produce when they believe themselves to be employing the spoken standard.

Each of the corpora was investigated on the basis of the following $\mathrm{MC}$ and $\mathrm{EC}$ considerations:

(a) MCs: the nature and frequency of first-position elements, and

(b) ECs: the presence versus absence of the declarative complementiser $d a t$, the nature and frequency of first-position elements in both cases, and then also the nature (lexical/thematic versus functional/nonthematic) of any verbs occurring in "illicit" second position.

Data involving ECs introduced by complementisers other than dat were also considered, but dat- and non-dat-clauses were examined separately. This approach represents a departure from previous studies investigating the behaviour of Afrikaans ECs - see footnote 21 - which all (barring the work by Feinauer) focus on the occurrence of VX patterns in embedded clauses generally, and not exclusively on dat-ECs. The primary motivation for the introduction of a dat/non-dat distinction in the present investigation was the initial (grammaticality judgement-based) profile which indicated that speakers were most likely to accept embedded V2 following dat and only at best sporadically after other complementisers. The possibility that a change specifically affecting dat-clauses might be underway, therefore, clearly had to be recognised. Interestingly, the existing literature on embedded V2 also focuses almost exclusively on this "semantically transparent" complementiser (Iatridou and Kroch 1992) ${ }^{24}$. McCloskey (1992: 37) states the observation which led to this state of affairs: "the pattern of distribution of embedded V2 structures corresponds exactly to the classically recognized domain of strict subcategorization". In other words, embedded V2 features in complement positions, but not in subject and extraposed positions ${ }^{25}$. Since "semantically transparent" complementisers like dat are the complementisers that introduce clausal complements, the lesser significance attributed to other complementisers within the V2 literature follows straightforwardly. 
Once the 3 corpora had been analysed, the results were compared with the initial profile and initial assumptions about the change that appears to be underway were reassessed. The facts are presented in section 4 below.

\section{V2 in Standard Afrikaans (AB)}

Standard Afrikaans exhibits the typical V2 distribution of a "well behaved" V2 language: whenever an overt complementiser is present, V2, which is otherwise the norm, is impossible.

Matrix clauses (MCs) are, therefore, obligatorily V2. What is notable about the MCs in the modern written corpus is the peculiar distribution of first position elements. Consider Table 2 in this regard.

Table 2: Distribution of first-position elements in modern written Afrikaans MCs

\begin{tabular}{|l|c|}
\hline Subject & $72 \%$ \\
\hline Adverbial & $27 \%$ \\
\hline Topicalised Element & $>1 \%$ \\
\hline
\end{tabular}

As the table clearly shows, the major indicator that Afrikaans is in fact a V2 language and not an SVO one like its fellow official language, English, is that inversion occurs following a clause-initial adverbial - see (6) and its translation equivalent, (7):

6a. $\quad$ Vandag lees ek die koerant

6b. *Vandag ek lees die koerant

7a. Today I am reading the paper

7b. *Today am I reading the paper

Interestingly, the adverbial-types that occur most commonly in initial position are:

(a) temporal adverbials and bare adverbs like today in (8) above; 
(b) other "circumstantial" adverbials, for example those specifying the place and general situation of the action in question (see Cinque 1998: 28); and

(c) connective adverbials, for example consequently, similarly, and furthermore.

Falk (1993: 217) refers to precisely this seemingly rather miscellaneous set of adverbials as "light adverbials" ${ }^{26}$.

Topicalised adverbials - and, likewise, topicalised objects - only occur extremely rarely: $1.21 \%$ of the $4330 \mathrm{MCs}$ investigated feature this kind of element in first position. Since there is such an obvious discrepancy between the first-position occurrence of adverbials and that of objects and other topicalised elements, we have considered these first-position elements separately. It should be noted, however, that this adverbial-vs-topic distinction is not generally drawn in the V2 literature: since nonsubjects in preverbal position definitively distinguish a clause as a V2 clause, the distinction that is most commonly drawn is between subjects and nonsubjects. Unaccountably - in the face of distributional evidence like that which is under discussion here, and also taking into account what is known about the frequency of "situative" and connective elements vis-a-vis other nonsubjects in Old English (see Bean 1983, and Stockwell 1984) - the notion of 'nonsubject' is often straightforwardly equated with that of 'topic' (see Vikner 1995: 69) ${ }^{27}$. As will emerge below, recognising the fact that nonsubject elements are actually frequently also nontopics plays a crucial role in the analysis of the Afrikaans V2 phenomena.

Turning our attention to $\mathrm{AB}$ ECs: in cases where an overt complementiser is present, V2 ordering is - as the classical theory predicts - impossible. These clauses, instead, are V-final. Thus, the subject-initial EC equivalent of (6a) above is (8a) below (complementiser and Vf underlined).

8a. $\quad$ Ek weet dat hy vandag die koerant lees

I know that he today the newspaper read

8b. *Ek weet dat hy lees vandag die koerant 
Indirect yes/no and wh-questions and wh-relatives are also V-final in Afrikaans - see examples (9b), (10b) and (11a) below. Note that, in contrast to their embedded counterparts, AB matrix interrogatives feature verb movement - compare (9a) and (10a) in this regard (complementiser and/or Vf underlined in all cases).

9a. Lees hy vandag die koerant?

Read he today the newspaper

9b. Ek wonder of hy vandag die koerant lees

I wonder if he today the newspaper read

9c. *Ek wonder of lees hy vandag die koerant

10a. Wat lees jy vandag?

What read you today

10b. Ek wonder wat jy vandag lees

I wonder what you today read

10c. *Ek wonder wat lees jy vandag

11a. Die man wat die koerant lees

The man which the newspaper read

11b. *Die man wat lees die koerant

The examples presented in (8) - (11) would seem to indicate that the following generalisation can be made about Afrikaans ECs: Afrikaans ECs are marked by verb-final ordering. This generalisation does indeed account for most Afrikaans ECs, but there is a very productive type of EC which does not conform to this pattern: the complementiserless equivalent of (8a) which is illustrated in (12) below (Vf underlined).

\section{Ek weet hy lees vandag die koerant}

I know he read today the newspaper

As (12) shows, Afrikaans permits V2 in embedded contexts in the absence of an overt complementiser. In the written Afrikaans corpus, over a third of clauses that could be 
rendered with overt dat are realised in the dat-less form: $63 \%$ of that-clauses involve overt dat, while $37 \%$ do not involve an overt complementiser. Similar figures (65\% versus $35 \%$ respectively) were found for the early Afrikaans corpus, indicating that dat-less ECs have always featured strongly in Afrikaans. The fact that such a high proportion of dat-less ECs occurs in written Afrikaans unambiguously indicates that this option is not the typically informal phenomenon that its English counterpart is often supposed to be. The important point about this complementiserless EC option as far as cross-linguistic comparisons go is that it is absolutely barred in Dutch (see Vikner 1995: 66; Webelhuth 1992: 87, 89; Feinauer 1990: 118; Zwart 1997a: 69; and example (13) below).

\section{3. *Ik weet de jongens lezen de krant}

I know the boys read the newspaper

In German, it is also only a highly restricted option which tends to occur when the embedded verb is clearly marked as such, bearing subjunctive morphology ${ }^{28}$ (see Den Besten 1983: 108 and example (14) below).

\section{Er meint, Johan habe/hat Maria gekuesst}

He thinks John have-SUBJ/has-IND Mary kissed

In his seminal article on matrix and embedded phenomena in Dutch and German, Den Besten - who refers to V2 as "verb preposing" - wonders “... why ... cases of Verb Preposing are so scanty in Dutch and German, whereas Afrikaans seems to be able to apply Verb Preposing in any subordinate clause with concomitant deletion of the complementizer". Presumably, this state of affairs is related to the fact that Afrikaans had been in close contact with English for over 100 years by the time it was finally standardised (see Ponelis 1993: 306-309). Crucially, as far as standard Afrikaans's overall V2 profile is concerned, the availability of these complementiserless "verb preposing" ECs means that Afrikaans - but not Dutch or German regularly permits V2 in embedded contexts. That is, unlike Dutch and German, V2 in Afrikaans is not restricted to matrix clause contexts; "well behaved" embedded V2 is also a possibility that is employed with considerable frequency. 
A notable feature of the dat-less EC is that it may, theoretically, feature the same broad range of first position elements that are permitted in MCs. Thus, in addition to subject-initial (12) above, adverbial-initial (15) and object-initial (16) are also options.

15. Ek weet vandag lees hy die koerant

I know today read he the newspaper

16. Ek weet die koerant lees hy vandag

I know the newspaper read he today

As was the case with the MCs (see Table 2 above), the data shows that topicalised elements are in practice not standardly fronted in ECs: in fact, the written corpus did not contain any fronted topicalisations in embedded contexts, while the early Afrikaans corpus featured a grand total of 2 topicalised first position elements in complementiserless ECs. First position adverbials are also severely restricted, the majority of those which did occur representing adjunction structures whose parenthetical nature is phonetically marked by comma notation. Compare (17) below.

17. Ek weet, as hy kom, gaan ons lekker partytjie

I know, if/when he come, go we nicely party

Table 3 summarises these facts.

Table 3: Distribution of first-position elements in early and modern written Afrikaans complementiserless ECs

\begin{tabular}{|l|l|l|}
\hline Type & Early Afrikaans & Modern Written Afrikaans \\
\hline Subject & $97 \%$ & $>97 \%$ \\
\hline Adverbial & $<2 \%$ & $>3 \%$ \\
\hline Topicalised Element & $<1 \%$ & $0 \%$ \\
\hline
\end{tabular}


In ECs introduced by an overt complementiser, any kind of nonsubject element is barred from occurring in clause-initial position. Compare (18) and (19) which respectively exemplify the unacceptability of adverbial- and topic-initial clauses following overt $d a t$.

18. *Ek weet dat vandag hy die koerant lees

19. *Ek weet dat die koerant hy vandag lees

Table 4 represents the cross-corporal distribution of first-position elements in the early and written Afrikaans corpora.

Table 4: Distribution of first-position elements in early and modern written Afrikaans datinitial ECs (V-final clauses)

\begin{tabular}{|l|l|l|}
\hline Type & Early Afrikaans & Modern Written Afrikaans \\
\hline Subject & $97 \%$ & $95 \%$ \\
\hline Adverbial & $<3 \%$ & $5 \%$ \\
\hline Topicalised Element & $0 \%$ & $0 \%$ \\
\hline
\end{tabular}

As the table clearly shows, ECs featuring an overt dat are incompatible with first-position topics. To the extent that speakers of Afrikaans require an embedded topicalisation ${ }^{29}$ option, they must, therefore, employ complementiserless ECs which theoretically permit clauseinitial topics (but see Table 3 above) ${ }^{30}$. As the nearly 3\% and 5\% occurrence of adverbialinitial clauses in the early and written corpora indicates, adverbial clauses may sometimes precede the embedded subject in dat-clauses. What should be noted about these adverbials, however, is that they are consistently and obligatorily of the interpollative type that also featured - at just under $2 \%$ and just over $3 \%$ in the early and written data respectively - in the complementiserless EC data. Compare (20) below.

20. Hy glo dat, as die span positief voel, hulle enige iemand kan klop

He believe that, if the team positive feel, they any one can beat 
Non-parenthetical adverbials and bare adverbs such as that illustrated in (19) did not feature at all in the early and written dat-clause data.

Returning to the issue of complementiser deletion possibilities in MSA: unlike its declarative counterpart, the interrogative complementiser of may not be omitted in $\mathrm{AB}$. Wh-relative elements may likewise not be omitted. $\mathrm{AB}$ yes/no questions and relative clauses are, therefore, both obligatorily V-final. Compare examples (21a) and (22a) and (9b-c), repeated here as (21b-c), and (11a-b), repeated here as (22b-c), in this regard.

21a. *Ek wonder lees hy vandag die koerant I wonder if he read today the newspaper

21b. *Ek wonder of lees hy vandag die koerant

21c. Ek wonder of hy vandag die koerant lees

22a. *Die man lees die koerant, is eensaam

The man read the newspaper is lonely

22b. *Die man wat lees die koerant, is eensaam

22c. Die man wat die koerant lees, is eensaam

\section{V2 in Modern Spoken Afrikaans (MSA)}

Investigation of the MSA corpus outlined in section 2.4 revealed clear similarities and differences between $\mathrm{AB}$ and MSA.

\subsection{Similarities between AB and MSA}

MSA MCs, like their standard Afrikaans counterparts, are obligatorily V2. What is once again notable, however, is the fact that speakers do not seem to readily exploit the topicalisation option that is, in theory, available to them (compare the comments made in section 3 about a parallel state of affairs which obtains in modern written Afrikaans). Table 5 provides a cross-corporal comparison of the MC first-position facts. 
Table 5: MC first-position elements in Afrikaans

\begin{tabular}{|l|l|l|l|}
\hline Type & Early Afrikaans & $\begin{array}{l}\text { Modern Written } \\
\text { Afrikaans }\end{array}$ & $\begin{array}{l}\text { Modern Spoken } \\
\text { Afrikaans }\end{array}$ \\
\hline Logical Subject & $67 \%$ & $72 \%$ & $80 \%$ \\
\hline Adverbial & $29 \%$ & $27 \%$ & $20 \%$ \\
\hline Topicalised Element & $<3 \%$ & $>1 \%$ & $>1 \%$ \\
\hline
\end{tabular}

As the rightmost column of Table 5 clearly shows, the occurrence of adverbials in immediately preverbal position - in the absence of robust evidence of other nonsubject firstposition elements - once again constitutes the spoken language "cue" that Afrikaans is in fact a V2 and not an SVO language. The fact that topicalised elements constitute less than $3 \%$ of the $\mathrm{MC}$ input even in early Afrikaans strongly suggests that adverbials have always acted as the salient V2 acquisition "flag". Interestingly, Hendriks and Prodeau (2000) have found that a similar situation obtains in Dutch, and Bean (1983), likewise, proposes that Old English V2 was essentially "flagged" by nontopicalised adverbials.

MSA, like AB, also readily permits the Afrikaans-specific complementiserless EC option. Compare Table 6 below:

Table 6: [+dat]/[-dat] alternation in Afrikaans

\begin{tabular}{|l|l|l|}
\hline & {$[+$ dat $]$} & [-dat] \\
\hline Early Afrikaans & $65 \%$ & $35 \%$ \\
\hline Modern Written Afrikaans & $63 \%$ & $37 \%$ \\
\hline Modern Spoken Afrikaans & $54 \%$ & $46 \%$ \\
\hline
\end{tabular}

As this table shows, complementiser omission is particularly common in MSA. This may indicate that there is, after all, some kind of modality effect, as there is in English. Complementiser omission is, however, certainly not solely conditioned by modality, as comparison with the non-spoken early and modern written data clearly shows.

As is the case in standard Afrikaans, embedded yes/no interrogatives and wh-relative clauses never exhibit V2 in MSA. 


\subsection{Differences between AB and MSA}

MSA also permits a variety of embedded V2 constructions which are barred in standard Afrikaans. Two of these are explicated in sections 4.2.1 and 4.2.2 below.

\subsubsection{Embedded V2 $w h$-interrogatives}

MSA allows embedded V2 $w$ h-interrogatives of the type illustrated in (23). This type of construction is unacceptable in standard Afrikaans (see (10c) above).

\section{Ek wonder wat het hy vandag weer aangevang?}

I wonder what has he today again done

As the comparison with (10a) shows, the embedded V2 wh-interrogative is formally identical to its MC counterpart, Wat het hy vandag weer aangevang? That cases like (23) do in fact involve genuine embedded clauses and not simply direct quotations following an appropriate matrix verb can sometimes, but not always, be shown via the characteristic "sequence of tenses" and pronoun change tests. As far as the MSA wh-interrogative data are concerned, however, a third, more consistently reliable test conclusively proved that the interrogatives in question were indeed embedded clauses and not citations: the absence of an intonation break between the matrix verb and the following $w h$-form. Evidently, therefore, we are dealing with matrix-style V2 $w h$-interrogatives in an embedded context.

During the initial pilot investigation, some native-speaker informants proved incapable of identifying these embedded V2 clauses as non-standard, an indication that this novel construction is already well entrenched ${ }^{31}$. Those who could identify the construction as nonstandard also indicated that the V2 form is commonly heard in spoken/informal Afrikaans. Investigation of the MSA corpus revealed that $70 \%$ of the embedded $w h$-interrogatives that speakers employed were in fact V2 clauses. Compare the data in Table 7 below. 
Table 7: Word order in embedded $w h$-interrogatives in Afrikaans

\begin{tabular}{|l|l|l|}
\hline & V-final & V2 \\
\hline Early Afrikaans & $99 \%$ & $1 \%$ \\
\hline Modern Written Afrikaans & $96 \%$ & $4 \%$ \\
\hline Modern Spoken Afrikaans & $30 \%$ & $70 \%$ \\
\hline
\end{tabular}

As the table clearly shows, the spoken data confirm the native-speakers' judgements regarding the widespread nature of embedded $w h$-interrogatives.

In view of the fact that "no Germanic language generally displays inversion in embedded questions" (Diesing 1990, footnote 10), the fact that MSA appears to be regularising inversion in embedded $w h$-interrogatives is a notable development ${ }^{32}$. Henry (1995) notes that Belfast English also permits embedded question inversion (EQI) as a productive option. Interestingly, Belfast English, like MSA, does not straightforwardly permit inversion in all interrogative ECs: while yes/no interrogatives are compatible with EQI in Belfast English, $w h$-interrogatives generally are $\operatorname{not}^{33}$. The Belfast English EQI profile is, therefore, a mirrorimage of its MSA counterpart, a fact which will prove significant in light of the analysis which is proposed for the MSA V2 change in section 5 below.

\subsubsection{Embedded V2 declaratives}

Compare (24) and (25) below.

\section{Ek dink dat jy sal die boek baie geniet}

I think that you will the book much enjoy

\section{Ek dink $\underline{\text { dat }}$ gister het hulle nou regtig drooggemaak ${ }^{34}$}

I think that yesterday have they now really dry-made (i.e. they made a mess yesterday)

Table 8 indicates the extent to which these embedded declaratives have already become established in MSA. By way of comparison, their occurrence in early and modern written Afrikaans is also represented. 
Table 8: Occurrence of $d a t$-initial V2 and V-final clauses in various corpora

\begin{tabular}{|l|l|l|l|}
\hline & Early Afrikaans & $\begin{array}{l}\text { Modern Written } \\
\text { Afrikaans }\end{array}$ & $\begin{array}{l}\text { Modern Spoken } \\
\text { Afrikaans }\end{array}$ \\
\hline V-final & $97 \%$ & $98 \%$ & $59 \%$ \\
\hline V2 & $<3 \%$ & $<2 \%$ & $41 \%^{35}$ \\
\hline
\end{tabular}

As the comparison with early and written Afrikaans clearly shows, the proportion of embedded V2 declaratives in MSA is significantly higher than that in the standard and prestandardisation forms of the language. As far as early Afrikaans is concerned, it should be noted that referring to "embedded V2" is something of a misnomer since the V2 figure of roughly $3 \%$ in fact reflects the presence in the corpora of extraposition structures with the finite verb in second position ${ }^{36}$. Examples (26) and (27) illustrate the kind of data at issue here.

26. ... dat ons moes teruggaan na Tati toe

... that we must back-go to Tati-ward ${ }^{37}$

27. ... dat sy mond water fer al die mooi goed

... that his mouth water for all the prettty stuff ${ }^{38}$

Assuming, in keeping with traditional analyses, that extraposition involves rightward movement of material across the finite verb which itself does not move $\mathrm{e}^{39}$, structures of this kind are unlikely to constitute bona fide instances of $\mathrm{V}$-in-C V2 ${ }^{40}$. Nevertheless - for reasons that will be made clear in section 5 below - we will temporarily ascribe V2 status to these verb-second strings. Similar structures in the other corpora were likewise included.

Even acknowledging the possibility that clauses such as (26) and (27) could represent instances of $\mathrm{V} 2$, the extremely low (less than 3\%) incidence of this kind of clause in early Afrikaans - which was very much a spoken language - clearly shows that the high frequency of embedded V2 in MSA cannot be regarded as a register- or modality-specific characteristic which has consistently been present in spoken Afrikaans. By all appearances, we are, therefore, dealing with an MSA innovation. 
Turning to the issue of first-position elements in MSA embedded V2 declaratives: during the initial pilot investigation, informants proved willing to accept subject- and adverbial-initial embedded declarative V2, although they consistently noted that these forms still, for the most part, sounded "lazy" to their ear. In general, the informants appeared to accept "illicit" subject-initial embedded V2 of the kind illustrated in (8b) above more readily than embedded V2 clauses headed by a (nonparenthetical) adverbial (see (18) above): all 15 informants conceded that they had heard subject-initial V2 ECs and that they regarded them as "acceptable in informal situations"; by contrast, only 9 of the subjects accepted adverbialinitial V2 ECs, and it was clear that even these informants were not equally happy with all of the adverbial-initial clauses that were presented to them. As far as object-initial clauses were concerned, however, the response was uniform: object-initial V2 ECs were absolutely rejected in all cases.

The distribution of first-position elements in the MSA data is presented in table 9 below.

Table 9: Comparison of first position elements in V-final and V2 clauses

\begin{tabular}{|l|l|l|}
\hline & V-final & V2 \\
\hline Logical subject & $98 \%$ & $81 \%$ \\
\hline Adverbial & $2 \%$ & $17 \%$ \\
\hline Topicalised Element & $0 \%$ & $<1 \%$ \\
\hline
\end{tabular}

As the table shows, topicalised elements barely feature in the MSA production data, indicating that the native-speaker informants were correct in rejecting these clauses as possible instances of embedded V2. The fact that $81 \%$ of V2 ECs feature the subject in first position straightforwardly accounts for the informants' judgements on that score, and the relatively high proportion of initial adverbials likewise explains why the majority of the informants indicated that adverbial-initial V2 ECs could pass muster. Closer examination of the adverbials which actually appear in first position revealed that adverbials preceding "illicit" EC V2 are mostly (14\%) of the parenthetical type ${ }^{41}$. Compare the attested examples below. 
28. Die reëls bepaal dat, as daar nie ' $n$ botsing tussen die bote is nie, kan daar nie ' $n$ diskwalifikasie wees nie

The rules determine that, if there not a collision between the boats is NEGATIVE, can there not a disqualification be NEGATIVE

29. Die enigste manier om misdaad hok te slaan is dat, voor die ou dit nog doen, moet hy bang wees

The only way INFINITIVAL COMPLEMENTISER crime cage to hit is that, before the guy it yet do, must he scared be (i.e. the only way to combat crime is to make potential criminals fear the consequences even before they act)

30. Ek dink dat, in 'n situasie waar rentekoerse styg, beweeg ons al hoe meer weg van 'n beleggingsbeleid

I think that, in a situation where interest-rates climb, move we ever more away from an investment-policy

Bare temporal adverbs (e.g. yesterday, today, Monday, etc.) also feature in initial position, but only to a limited extent. Taking the distribution facts into account, it becomes clear why the informants' adverbial judgements were not more robust: during the initial pilot, they were presented with an undifferentiated assortment of adverbial-initial clauses, whereas, in reality, only a subset of the class of adverbials ever features in the relevant embedded context. When the informants were retested, bearing in mind that the nature of the first-position adverbial might be significant, it emerged that this is indeed the case. Disregarding parenthetical adverbials, the only class of adverbials that were generally accepted by the informants were temporal adverbials. Even in this case, however, it was clear that informants draw a distinction between bare temporal adverbs and phrasal adverbial forms. Thus, cases like (31) received a positive judgement from all of the informants, whereas examples like (32) were subject to more variable, but mostly negative judgements.

31. Ek kan sommer sien dat vandag gaan die vonke spat I can just see that today go the sparks fly 
32. */? Ek weet dat in die oggend sal ons moet wikkel as ons betyds wil wees

I know that in the morning shall we have-to hurry if we in-time want to-be

Focusing specifically on the interpolated constituents that occurred in preverbal position in the MSA data: since these are generally of some length, it is not surprising that "ungrammatical" V2-like structures should often follow, anacoluthon-style. The crucial point as far as the MSA data are concerned, however, is that these parenthetical adverbials cannot properly be regarded as occupying the same position as logical subjects, circumstantial and connective adverbials or topicalised objects in genuine V2 constructions: the characteristic comma intonation associated with these constituents would seem to "mark" the slot in which they occur as one distinct from the usual pre-V2 Spec-CP slot ${ }^{42}$. Assuming this interpretation of the prosodic cues to be correct, V2 ECs featuring parenthetical adverbials in first position cannot in fact be treated as instances of genuine embedded V2. This is the assumption with which we will proceed.

In addition to the nature of the first position element, investigation of the MSA showed that the nature of the verb occurring "illicitly" in second position also constitutes a significant V2facilitating factor. Consider Table 10 below.

Table 10: Distribution of verb-types occurring in EC second position

\begin{tabular}{|l|l|}
\hline Verb Type & \% Occurrence \\
\hline Lexical main verb (e.g. lees - "read") & 16 \\
\hline Copula (e.g. is - "is") & 35 \\
\hline Modal (e.g. moet - "must") & 29 \\
\hline Auxiliary (e.g. het - (non-possessive) "has") & 20 \\
\hline
\end{tabular}

As the table clearly shows, $84 \%$ of the verbs occurring in second position are nonthematic/functional verbs. In tests following the analysis of the MSA corpus, informants consistently rejected EC V2 clauses with thematic verbs in second position as "bad", while those featuring functional second position verbs were not dismissed in this way. Subsequent observation of spontaneous conversation between native-speakers has likewise reinforced the hypothesis that thematic and functional verbs behave differently in the context of dat-clauses: 
out of 58 recorded instances of this kind of spontaneous conversation EC V2, only a single one involves a thematic verb, namely high-frequency eet. Investigation of examples cited by other researchers who have worked on Afrikaans V2 similarly reveal the predominance of functional verbs in EC V2 contexts. All these considerations strongly suggest that the nature of the second position verb is a significant factor regulating the perceived acceptability of V2 in embedded contexts.

The nature of the matrix verb - a consideration which, unlike that of the EC verb, has generated substantial debate in the literature (see Vikner's 1995 discussion of "bridge verbs") - also appears to play a role in determining the acceptability of embedded V2. In the MSA corpus, embedded V2 almost exceptionlessly occurred after verba sentiendi et dicendi, with dink, sien, sê, weet, glo and voel accounting for more than $90 \%$ of the selecting MC verbs. These verbs are prominently and consistently cited in bridge verb lists (see those mentioned in section 2.3 above). They are, furthermore, verbs that are commonly employed in the kind of "strongly affirming" contexts that Andersson (1975) and Dunbar (1979) identify as the characteristic embedded V2 domain. Embedded V2 in the corpus does occur sporadically after MC verbs which are incompatible with strong affirmation (e.g. the negative, negated, and irrealis verbs discussed in (De Haan and Weerman 1985), (Iatridou and Kroch 1992: 4ff), and (Vikner 1995: 71ff)), but these cases seem to represent a rather irregular and seemingly distinct phenomenon: all the native-speakers who were tested judged utterances of this kind as "bad" or, at best, as performance errors. By virtue of their extremely infrequent occurrence and the status assigned to them by native-speakers, we take the view that these embedded V2 clauses should not, as has sometimes been the case (see Robbers 1997 and Vriends 1998 in connection with Afrikaans), be regarded as counterexamples to the generalisation that appears to be valid, namely that declarative embedded V2 is licensed in ECs expressing fact(s) which the speaker wishes to assert in no uncertain terms. The fact that V2 is, particularly in "well behaved" V2 languages, such an unambiguous marker of matrix clause status and matrix clauses are, in turn, most commonly associated with information that is discoursally more salient than that realised in embedded clauses provides a straightforward discourse motivation for the introduction of embedded V2 in "strongly affirmative" contexts. 
Concluding on the matter of verbs characteristically associated with embedded V2, therefore, it is clear that both the nature of the matrix verb and the nature of the embedded verb are relevant considerations. As far as the former is concerned, it appears to be the case that verbs that may introduce statements with which the speaker strongly identifies or agrees are also the ones that license embedded V2. As far as the embedded verb is concerned, it is clear that functional verbs are far more compatible with embedded V2 than are their thematic counterparts.

\subsection{Conclusion}

What the investigation of the three corpora clearly shows is that the distribution of embedded V2 in MSA is currently in a state of flux. On the surface, it would appear that further MC V2 options are being extended to ECs: embedded $w h$-interrogatives in the MSA corpus are more commonly realised with the finite verb in second position than in the verb-final standard form, while certain declaratives following the complementiser dat also frequently present as V2 clauses. Clearly, this latter innovation, which features V2 in the presence of an overt complementiser, jeopardises Afrikaans's status as a "well behaved" V2 language. The question now is whether MSA - today's spoken language which may well be tomorrow's standard - is evolving into a limited embedded V2 language.

\section{Proposed Analysis}

In view of the fact that novel embedded V2 constructions are evidently being introduced into MSA in a staggered fashion, the explanandum that we face is: why is the change that appears to be underway taking the route that it is? That is, why should embedded V2 whinterrogatives already be further along the road to complete acceptability than subject-initial declarative clauses? And why should embedded topicalisation, yes/no questions and relative structures be immune to the change?

Intuitively, it would be satisfying to be able to say that the input data that Afrikaans speakers are confronted with plays some role in the change. In the case of the MSA change, this kind of intuitively satisfying input-based explanation appears to be plausible. Consider, for 
example, the fact that the embedded V2 constructions which are gaining currency in MSA are precisely those for which there is abundant MC evidence. Recall that MCs are obligatorily V2 in Afrikaans. Recall, furthermore, that certain theoretically available V2 options - for example, topicalisation structures - are only very infrequently attested in actual production, whereas others - subject- and unmarked adverbial-initial structures - form the bulk (nearly 99\%) of MC structures. In all likelihood, taking into account their MC prominence, it is, therefore, no coincidence that it is precisely subject- and (parenthetical) unmarked adverbialinitial declaratives that are starting to feature V2 in embedded contexts. The fact that declarative dat is so frequently omitted means that speakers are accustomed to hearing declarative ECs featuring the verb in second position, a factor which undoubtedly also plays a role in letting V2 in the presence of overt dat fall more easily on the Afrikaans ear. Note, by contrast, that interrogative of may never be omitted in standard Afrikaans (although this is permitted in some regional dialects of Afrikaans - see Lubbe 1983 and Feinauer 1987). Consequently, speakers never hear V2 in the context of embedded yes/no interrogatives, which could explain why these are entirely absent from the MSA data ${ }^{43}$. The same can be said for the non-occurrence of V2 wh-relatives in the MSA data: standard Afrikaans does not present the option of omitting $w h$-relatives; therefore, speakers do not produce the kind of V2 structure that would arise under omission conditions in the presence of the overt $w h$-relative either. Wh-interrogatives are clearly the furthest along the road to acceptability, and this circumstance, too, can be explained in an intuitive way: wh-questions do not involve an overt interrogative complementiser; therefore, there is no "obstacle", as it were, to overgeneralising/ extending the MC pattern to ECs.

While the kind of intuitive explanation offered above may be appealing from a commonsense point of view, it is, of course, not adequate from a theoretical perspective. How, for example, would these suggestions be translated into a Minimalist explanation?

The proposal is as follows:

Firstly, the disappearance, in MSA production, of an overt ordering distinction between MC and EC $w h$-interrogative ordering is registered in speakers' internal grammars as the loss of a featural distinction between the relevant $\mathrm{C}$-heads in matrix and embedded $w h$-clauses. More 
specifically, whereas standard Afrikaans unselected (matrix) $[+\mathrm{Q},+w h] \mathrm{C}$ is - in Chomsky's (1995 and 1998) terms - associated with strong V-features, and selected (embedded) [+Q, + wh] $\mathrm{C}$ is associated with weak V-features, MSA has only a single [+Q, +wh] C, namely the matrix-style one which is specified for a strong V-feature. Note that the fact that the increase in V2 structures does not affect $w h$-relatives unambiguously indicates that feature strength assuming this is indeed the actual trigger for movement - cannot (always) straightforwardly be associated with particular functional heads (e.g. T, C, D) per se; in addition to being associated with the complete feature complex associated with functional heads, it appears to be possible for $\mathrm{V}$ - and $\mathrm{N}$-feature strength to be associated with specific sublabels of a given functional category ${ }^{44}$.

Secondly, the significantly less frequent appearance, in MSA production, of what superficially appear to be declarative embedded V2 structures currently has the character of a variation phenomenon: speakers do not consistently employ this option. At present, it would seem that these structures do not reflect any reanalysis of the feature-strength of embedded T, but merely the absence of "first phase" vP raising to Spec-TP - that is, the movement which would ordinarily produce the characteristic EC V-final ordering (see section 2.2). Consequently, superficially MC-like V2 structures are generated. The fact that typical Telements - copulas, modals and auxiliaries - most commonly occur in the second position of these EC structures follows from the fact that these elements are merged under T; finite verbs that would require raising-to-T, i.e. the lexical verbs that are merged under $\mathrm{V}$, only feature infrequently in the second position of the innovative MSA declarative clauses. If one assumes that the feature-strength associated with MSA T is the same as that associated with $\mathrm{AB} T$, this follows straightforwardly: $\mathrm{T}$ would have to be strong for lexical verbs to raise out of $\mathrm{vP}$ and this is patently not the case in $\mathrm{AB}$ (see section 2.2). The fact that lexical verbs do occasionally (in $16 \%$ of cases) feature in second position would, at the moment, seem to be the consequence of non-feature-driven overgeneralisation. That is, speakers receiving relatively robust embedded V2 input with T-elements in second position overgeneralise and begin to allow lexical verbs in second position as well, thereby replicating the MC situation where lexical and functional verbs behave identically. Should the current embedded V2 pattern become more widespread, regularly extending to lexical verbs, a change in the features of embedded $\mathrm{T}$ and also in the licensing of Spec-T, would follow. Specifically, Spec- 
T would presumably have to be licensed in the way required by the original EPP requirement - by raising of the subject XP; and embedded T would have to acquire a strong V-feature. In the absence of a base-generated T-element, this strong feature would require obligatory raising of the finite (lexical) verb to $\mathrm{T}$, something which does not happen in MCs where the $\mathrm{V}$-feature on $\mathrm{T}$ is weak ${ }^{45}$.

What is, therefore, proposed for the declarative embedded V2 constructions that are starting to gain currency in MSA, is that these superficial V2 clauses are not in fact genuine V2 constructions. Remembering that "genuine V2" is defined as V-in-C, constructions featuring $\mathrm{V}$-in-T clearly cannot qualify as instances of genuine $\mathrm{V} 2^{46}$. The crucial motivation for the proposal that the innovative V2 structures in MSA in fact involve movement to $\mathrm{T}$ and not to $\mathrm{C}$ lies in:

(a) the nature of the first-position elements that these constructions feature. Subjects have traditionally been analysed as Spec-TP elements; therefore, analysing the MSA subjectinitial ECs as TPs would seem to be uncontroversial. Zwart (1997a) and Travis (1984), in fact, make similar proposals for subject-initial MCs in Dutch and German respectively; and

(b) the nature of the verbs occurring in second position. As indicated in Table 10, the vast majority of "illicit" second-position verbs are in fact prototypical T-elements - copulas, modals, and auxiliaries - which would, in terms of the clause structure outlined in section 2.2 , be merged under $\mathrm{T}$.

If we now reconsider the question posed at the end of section 4 - whether the increase in embedded V2 structures points to (the beginnings of) a change in terms of which MSA will ultimately evolve into a limited embedded V2 language - the answer would seem to be no: all of MSA's ostensibly innovative embedded V2 structures cannot actually be analysed as genuine V2 structures. The changes that appear to be underway in MSA do not straightforwardly involve an across-the-board increase in permissible V2 patterns. In reality, two distinct changes seem to be underway: one which is already well entrenched and which is affecting wh-interrogatives, and a second, which is far less advanced, affecting certain 
embedded declaratives. The former change is affecting permissible V2 options - that is, this change is introducing an innovative genuine V2 possibility. The latter change, by contrast, only superficially appears to be a V2 change; in reality, frequently attested MC (mostly SVO) patterns are being generalised to embedded contexts. Since limited embedded V2 languages do not permit embedded V2 interrogatives - nor indeed do generalised embedded V2 languages (see Bobalijk and Thráinsson 1998: 48) - the genuine V2 interrogative change is clearly not moving MSA in the direction of the Mainland Scandinavian languages. By virtue of the fact that the innovative declarative clauses are not in fact genuine V2 clauses, this second change would likewise not seem to be shaping MSA into more of a limited embedded V2 language.

\section{Conclusion}

In the preceding discussion, the V2 characteristics of Afrikaans were highlighted. As was shown, this language is currently undergoing a process of linguistic change which superficially appears to be altering its embedded V2 characteristics. Specifically, it was shown that embedded $w h$-interrogatives and certain kinds of mostly subject-initial declarative embedded clauses appear to be developing a tolerance of the V2 options which are available in the case of their matrix counterparts. The extension of the MC V2 analysis seems plausible enough in the case of the novel MSA embedded V2 wh-interrogatives: MSA does indeed appear to be unique among the Germanic languages in permitting embedded V2 wh-

interrogatives ${ }^{47}$. A closer investigation of the first position and verbal elements which are involved in the declarative change, however, suggests that these innovative embedded clauses may only superficially be V2 clauses. Taking into account the fact that the first-position elements involved in the novel declarative instances of embedded V2 are typical TP-related elements and that, additionally, the verbs that feature in second position are typical $\mathrm{T}$ elements, analysing these innovative clauses as TPs that do not involve genuine V-in-C V2 seems justified.

In terms of the analysis which is presented here, the answer to the question posed in the title of this paper is, therefore, simultaneously yes and no. On the one hand, AB verb second does indeed appear to be a unitary phenomenon, namely genuine V2. On the assumption, contra 
Zwart (1993/1997a), that V2 in so-called "well behaved" V2 languages necessarily involves $\mathrm{V}$-in-C (see section 2.2 above), there is no reason to doubt that verb second strings in $\mathrm{AB}$ are CPs. AB MCs feature both subject and nonsubject elements in first position (see Table 2). Despite the fact that speakers in practice appear to employ the nonsubject option only infrequently, the same options also exist in complementiserless ECs. By contrast, MSA verb second structures cannot summarily be analysed in a unitary way as CPs with V-in-C. While MSA MCs and complementiserless ECs are amenable to the same analysis as their $\mathrm{AB}$ counterparts, only the innovative $w h$-interrogatives in MSA appear to warrant a classical Vin-C analysis. As was indicated above, the distribution of first- and second-position elements in the innovative MSA embedded declaratives suggests that these are in fact TPs with V-in-T. If this analysis is correct, the appropriate conclusion for MSA appears to be that it is still a "well behaved" V2 language with all the genuine V2 options that it permits being amenable to a unitary $\mathrm{V}$-in-C analysis. From a purely surface perspective, however, the opposite conclusion emerges: everything that superficially appears to be V2 is not in fact genuine Vin-C V2, with some verb second strings requiring a TP analysis rather than the classic $\mathrm{CP}$ analysis. 


\section{NOTES}

1. Earlier versions of (parts of) this paper were presented at the Twelfth International Conference on Theoretical and Applied Linguistics in Thessaloniki (April 1998); the First International Conference on Linguistics in Southern Africa (Cape Town, January 2000); the Third Durham Postgraduate Conference in Theoretical and Applied Linguistics (June 2000); the LAGB Autumn Meeting (Durham, September 2000); the First European Workshop on Afrikaans Extra Muros (EWAfrEM) in Leipzig (September 2000); and various research seminars held at the Research Centre for English and Applied Linguistics, University of Cambridge. Thanks to the various audiences for their comments; to my informants for their judgements; and, particularly, to Adam Ledgeway for illuminating discussions which contributed greatly to the present analysis.

2. So-called "remnant topicalisation" (see inter alia Den Besten and Webelhuth 1987 and Müller 1997) may at first sight not appear to involve an initial phrasal constituent compare Gelees het ek die boek nog nie, maar ek het al daarna gekyk (remnant underlined - "Read have I the book not yet, but I have already there-at looked"). The fact that such topicalisation constructions can also be realised - albeit less idiomatically/ felicitously - via complete vP fronting - i.e. Die boek gelees het ek nog nie (vP underlined) - has been suggested to indicate that these constructions may in fact involve the fronting of an entire vP containing an unspelled-out (moved) DP object trace, i.e. a legitimate phrasal category. This matter will not concern us here.

3. See Vikner 1995 for references to some of the major discussions of V2 until 1995, and Vikner and Schwartz 1996 and Zwart 1997a for references to subsequent writings on the subject.

4. (Oosthuizen 1996) and (Vriends 1998) represent two exceptions to this generalisation.

5. See inter alia Raidt 1983, Ponelis 1993, and Donaldson 1993. 
6. In compound (perfective) infinitives, the Dutch infinitive hebben is realised as Afrikaans het which is more commonly a finite form, as Table 1 shows.

Compare: $\quad$ 1. $\quad$ Ek wil dit sien ("I want it see-INF")

2. Ek wou dit gesien het ("I wanted it seen have-INF", i.e. I had wanted to see it)

7. See inter alia Johnson 1990, Holmberg and Platzack 1995, Roberts 1993: 267ff, and Rohrbacher 1994.

8. See inter alia alia Zwart 1997a: 136ff and 256ff, Haegeman 1992, and Bayer 1983.

9. As ek betyds vertrek het, sou ek betyds daar gewees het ("If I on-time left had, would I on-time there been have") may be alternatively realised as Het ek betyds vertrek, sou ek betyds daar gewees het. Thus, the finite verb may only occur clause-initially (i.e. in the same position as the complementiser as in the first example) when the complementiser is not itself present. This would seem to suggest that the two elements are in complementary distribution, competing, as it were, for the same structural position.

10. Although this is not usually highlighted in the literature - nor is it immediately obvious when one compares subject-initial matrix and embedded clauses - it should be noted that the Northern Germanic Mainland Scandinavian languages also exhibit a matrixembedded asymmetry: matrix clauses are obligatorily V2, as indicated in section 2.3, while embedded clauses most commonly display (English-style) SVO order with the possibility of adverbial and negation elements intervening between the subject and Vf.

11. See Zwart $1997 \mathrm{~b}$ for a discussion of the fundamental misconception underlying preKayneian SOV analyses and, more generally, all analyses which postulate that one of the observed surface orderings is necessarily primary in some sense.

12. Chomsky (1995: 368ff) considers two alternative Spec-vP orderings: a "stacking" order and a "leapfrogging" order as Bobalijk (1995: 110ff) describes them. The "stacking" order, in terms of which the object raises to inner Spec-vP, is adopted here. Quite aside 
from the fact that this ordering straightforwardly allows us to derive the familiar Germanic embedded SOV ordering via vP raising, this option - which is also favoured by inter alia Koizumi (1993), Miyagawa (1993), Bobalijk (1995), Jonas (1996), and Ura (2000) - allows a vastly simpler formulation of the MLC than the "leapfrogging" alternative.

13. Under the Chomsky (1999) analysis in terms of "Attract", the complement would presumably raise to identify the underspecified D-related feature bundle associated with inner Spec-v.

14. Within a Chomskyan Probe-Goal analysis, the non-raising of $\mathrm{V}$ to $\mathrm{T}$ might, on the one hand, be accounted for by proposing that the T-head does not operate like an underspecified Probe in search of an appropriately specified lexical head. Alternatively, on the view that most head raising is in fact a PF phenomenon, the non-raising of $\mathrm{V}$ to $\mathrm{T}$ might simply be viewed as a syntactically insignificant fact (see Chomsky 1999: 30 where the often observed fact that the presence or absence of verb raising does not seem to correlate with interpretational distinctions is highlighted).

15. Viewing T/I as weak represents a departure from Lightfoot (1991 and 1999), Kayne (1994), Vikner (1995), Zwart (1997a), Bobalijk and Thráinsson (1998), and Haegeman (1998), and others who postulate V-to-I movement in the traditional SOV languages. Note too, however, that, barring Zwart (1997) and Haegeman (1998), linguists subscribing to this view all assume an underlying SOV base-order for the languages in question. They, therefore, as Vikner (1995: 152ff) in particular emphasises, actually assume V-to-I movement by default, as it were - i.e.since VP and IP are both head-final, I follows $\mathrm{V}$ in the linear ordering, making it impossible to confirm the exact location of a final-position verb: does it remain in V or has it moved, string-vacuously, to I?

16. Chomsky (1999: 31) mentions in passing that, although the Extended Projection Principle (EPP) has conventionally (since (Chomsky 1982)) been regarded as necessitating the presence of subject-related features in Spec-T (originally, Spec-IP), the theoretical apparatus which he proposes provides no obvious basis for this. Thus, he 
leaves open the possibility that Spec-T may in fact be licensed by V-to-T raising (as proposed by Alexiadou and Anagnostopoulou (1998) for Modern Greek) or by VP (sic)to-Spec-T raising. To the best of our knowledge, this latter option has not been explored by anyone to date. Biberauer (2001) proposes that precisely this kind of nonsubject-related EPP-licensing mechanism was operative in Common Germanic, and that the Germanic SOV languages (at the very least) still exhibit this peculiar Spec-T licensing mechanism. This idea is currently still very much work in progress. The distribution of German, Yiddish and Icelandic expletives would, however, seem to offer support for this hypothesis (see inter alia Falk 1993 and Abraham 1993), as would the SOV data discussed by Van Gelderen (1993) in her refutation of the idea that these languages - or, indeed, Old English - license Spec-TP. In a similar vein, Haider (1991) and Koster (1986) also independently propose for German and Dutch respectively that these languages may in fact not license Spec-TP. The present proposal does not exclude the projection of Spec-TP, in the way that the aforementioned authors have suggested, but it seeks to account for the same data and intuitions by proposing that the nature of Spec-TP in the Germanic SOV languages may differ fundamentally from that in its SVO counterparts.

17. As Holmberg (2000), Adam Ledgeway (p.c.), Ian Roberts (p.c.), and others have noted, the fact that it has proved impossible to isolate a syntactic motivation for V2 would seem to suggest that Chomsky (1995: 387, note 6, and 1991: 31) is correct in relegating this particular word order phenomenon to the PF component. The summaries in (Platzack 1985) and (Vikner 1995: 51-64) give some indication of the kinds of syntactic trigger proposals that have been offered over the past 25 or so years. (Kathol 1990 and 1995), (Uszkoreit 1987), and (Berman 2000) represent just three non-Chomskyan approaches to the same phenomenon.

18. Note that this is not an uncontroversial assumption. Since (Travis 1984), antisymmetric analyses - in terms of which a distinction is drawn between subject-initial clauses (which are regarded as TPs) and nonsubject-initial clauses (which are regarded as CPs) have featured strongly in the V2 literature (see Schwartz and Vikner 1989 for a review of the main proponents of this view). Clearly, this kind of analysis entails that V2 does 
not necessarily always involve Vf-in-C, as assumed by Classical theorists. The author's objection to the validity of asymmetric V2 analyses is two-fold. Firstly, the observation that V2 and overt complementisers are incompatible in "well behaved" V2 languages is a robust one. If one assumes that this incompatibility is straightforwardly the consequence of "competition" for the same structural position (C), we have a simple explanation for this state of affairs. By contrast, assuming that Vf may be in either $\mathrm{C}$ or $\mathrm{T}$, depending on the nature of the initial element, implies that two distinct explanations are required to account for the incompatibility facts: the "competition" one already mentioned above and, additionally, a separate one which explains why embedded V2 subject-initial clauses are as unacceptable as their nonsubject-initial counterparts, despite the fact that $\mathrm{Vf}$ is in $\mathrm{T}$ in this case and, therefore, not competing for the $\mathrm{C}$ position. Secondly, proposing that subject-initial clauses are in fact TPs - as they presumably are in English and other non-V2 languages - calls for an explanation as to why English-style adverbial adjunction is strictly prohibited in the case of the "well behaved" V2 languages. A suitable XP position is, after all, available in Spec-CP; yet this placement possibility is never exploited. If one assumes that all V2 clauses are CPs, this predicament does not arise: Spec-CP is already occupied by the pre-verbal constituent which, therefore, precludes the possibility of English-style adverbial-initial clauses. In view of these complications, the asymmetric analysis of V2 phenomena is rejected here and the classical view that V2 involves Vf-in-C maintained.

19. Residual V2 has also been attributed to languages not belonging to the Germanic language family - see Roberts 1993, the contributions in Van Kemenade and Vincent 1997, and also Holmberg 2000, Borsley and Kathol 2000, and Willis 1996.

20. As Barnes (1992) and Jonas (1996) point out, it is not strictly accurate to classify Faroese in toto as a limited embedded V2 language since this language currently features a dialect split in terms of which one variety - Jonas's "Faroese 1" - permits general embedded V2 in the Icelandic way, while the other - designated "Faroese 2" by Jonas - behaves like the Mainland Scandinavian languages. Since Faroese 2 is the dialect which is spoken in the most populous city (Torshavn), Faroese is, however, classified with the Mainland branch of Scandinavian in this instance. 
21. See Van Riemsdijk and Williams 1986: 294.

22. This observation had also been made by inter alia Steyn (1977), Lubbe (1983), Olivier (1985), Feinauer (1987, 1989 and 1990), and the researchers involved with the 1982 Rand Afrikaans University corpus project.

23. Contra more traditional views (see inter alia Conradie 1986 and the contributions in Botha et al. 1989), we follow Deumert (1999) in dating the origin of Afrikaans as a systematically distinct offshoot of its parent, Dutch, to the late 1800/early 1900 period. Until 1925, when Afrikaans was recognised as a linguistic entity distinct from its parent, Dutch and English were South Africa's two official languages. Since a standard form was only finally codified in 1925 , it is reasonable to suppose that people who wrote Afrikaans rather than Dutch before that date would have been writing the language that they spoke, and not some artificial prescriptive variety. The fact that leading proponents of the Afrikaans Language Movement at the end of the nineteenth century strongly encouraged people to start writing as they spoke (see Conradie 1986: $105 \mathrm{ff}$ and Raidt 1971: 205ff) further supports the validity of this assumption.

24. Uhmann's (1998) work on weil-clauses in German represents the only notable exception of which I am aware. Schönenberger (2000) notes that Uhmann's observations regarding weil hold for the Swiss German counterpart, wil, as well.

25. According to Anders Holmberg (p.c.), this generalisation applies even in the case of the generalised embedded V2 languages, Yiddish and Icelandic (see also Vikner 1995: 67 and sections 4.1 .4 and 5.2 in this regard).

26. Falk (1993: 217) observes that, in Swedish, this class of light adverbials may intervene between the subject and Vf, even in V2 clauses.

27. Zwart (1997a: 28) notes that, although he adopts the term "topicalization" to refer to the fronting of XPs in non-interrogative inversion constructions, neither the topic-comment 
distinction nor its focus-ground counterpart is instrumental in characterising fronting phenomena in Dutch. This observation appears to hold for nonsubject-initial declaratives in all the Germanic languages.

28. It should be noted that, despite the undeniable restrictions on their occurrence, German complementiserless ECs do not exclusively involve subjunctive embedded verbs. Particularly in modern German, the indicative is becoming increasingly common in this context (hence the alternation indicated in example (14) in the main text). Feinauer (1990: 118) points out that this is especially the case in ECs following factive weiss ("know").

29. Recall that clauses involving topicalisation represent a subset of clauses featuring nonsubjects in initial position.

30. As has frequently been noted in the literature, topicalisation in embedded contexts is less "urgent" than in MCs since the prominence of a constituent decreases in proportion to its degree of embedding (see inter alia Venneman 1974, Langacker 1974, and Dunbar 1979).

31. Oosthuizen (1996) discusses the alternation between AB V-final $w h$-interrogatives and the non-standard V2 form as an instance of (word order) variation, and Steyn (1977), Lubbe (1983), Olivier (1985), and Feinauer (1987) also register the occurrence of this alternation.

32. Despite the fact that Diesing's generalisation is, as far as we have been able to ascertain, accurate insofar as it relates to the regular grammaticalised occurrence of inversion in embedded ( $w h$-interrogatives, it is interesting to note the widespread nature of this kind of inversion in various colloquial and non-native varieties of English. Thus, Francis Nolan has pointed out (p.c.) that indirect questions generally, both the yes/no and the wh-variety, seem to be on the rise in British English. Consider in this regard I asked him what were his reasons for rejecting the deal and I asked him would he now be accepting the deal. Similarly, frequent usage of inverted $w h$-forms is observable in the 
otherwise relatively proficient English of non-natives from a diversity of linguistic backgrounds. Consider the attested examples below:.

(1) And they will still have to prove how are they going to handle this totally new era which the world is approaching (Former South African Minister of Foreign Affairs, Pik Botha)

(2) I want to know what $\underline{\text { is }}$ the position ( $\mathrm{PhD}$-educated Singaporean Government Minister)

33. Henry (1995: 106) points out that there appear to be two distinct EQI dialects, one which permits both regular yes/no EQI and sporadic, but by no means productive wh EQI, and another which exclusively permits EQI in the context of yes/no interrogatives, but never in $w h$-interrogatives. In the case of both dialects, therefore, yes/no and $w h$ interrogatives are not equally compatible with EQI.

34. These are both attested examples, produced by two native-speakers.

35. Note that ECs involving unmodified intransitive verbs which superficially appear to be V2 clauses, but could also be prescriptively correct V-final clauses (e.g. Ek dink dat hy slaap - "I think that he sleep"), were excluded for the purposes of this comparison. By virtue of the fact that clauses of this kind do, on the surface, exhibit verb-second ordering and might, therefore, be misanalysed as embedded V2 clauses, they were counted separately. Just under $1 \%$ of the MSA dat-clauses were found to be ambiguous in this way. In total, then, $42 \%$ of the of MSA dat-clauses exhibit superficial verbsecond ordering.

36. Extraposition/“leaking” phenomena featured consistently in each of the three corpora with approximately a third of all potential extraposition environments (i.e. those involving modifying adverbial clauses) actually featuring extraposition. Consultation with 6 Dutch native-speakers suggests that this language also permits extraposition quite readily, whereas similar consultation with 9 native German speakers resulted in all of the informants spontaneously producing non-extraposed clauses while only accepting 
extraposed examples that were presented to them as "not quite right" (4 informants) or "(rather) bad" (5 informants).

37. This example is from Chapter 7 of S.J. du Toit's Di Koningin fan Skeba (1899: 23).

38. This example is from Chapter 5 of S.J. du Toit's Di Koningin fan Skeba (1899: 18).

39. Before the Universal Base Hypothesis was extended to the traditional SOV Germanic languages, the consensus on so-called extraposition or "leaking" structures was that these involve movement of clause-internal material to some right-adjoined node. See Beerman et al. 1997 for discussions of both early and more recent approaches to extraposition phenomena.

40. The fact that the early Afrikaans corpus did not contain a single unambiguous instance of embedded V2 would further seem to strengthen the hypothesis that the ostensible extraposition strings do not involve V2 in the classical sense.

41. Note that the $2 \%$ of V-final dat-clauses with adverbials in first position all involve parenthetical initial adverbials as well.

42. McCloskey (1992) also highlights the syntactic peculiarity of parentheticals, and Browning (1996: 238, cited in Cinque 1999: 181, footnote 87) takes the extreme view that parenthetical intonation in fact signals that the constituent in question is not part of the syntactic representation.

43. As Henry (1995) notes, Belfast English regularly permits embedded V2 yes/no interrogatives. This variety also permits the omission of the interrogative complementiser, however. Therefore, the possibility of embedded V2 yes/no interrogatives receives a straightforward explanation in terms of the proposal for Afrikaans: the Belfast English yes/no interrogative situation parallels the MSA dat declarative one. 
44. Henry (1995) also points to this fact in her analysis of Belfast English. Since the sublabel in question here is actually [wh] which is an interpretable feature of the kind which arguably functions to clause-type sentences, it is tempting to suggest that [wh] may in fact itself be associated with a strong feature which then triggers the observed movement. This would, of course, represent a departure from Chomsky's (1995) proposal that only uninterpretable categorial features can trigger movement. From an intuitive, acquisition-centred point of view, wh-movement - like Negative Movement does, however, appear to be "flagged" principally by the presumably salient interpretable feature on the wh-element. Postulating that it is actually a categorial feature associated with $[\mathrm{wh}] /[\mathrm{neg}]$, by contrast, smacks strongly of a regularising assumption which is exclusively motivated on theory-internal grounds. Clearly, further research is needed on this point.

45. Recall that the lexical verb in MCs raises into the domain of $\mathrm{T}$ via $\mathrm{vP}$ raising.

46. Weerman (1989: 19) also draws this distinction between genuine V2 - which he designates "Vf2" - and superficial V2 which merely "happen[s] to result in a V2-effect", the overt finite-verb-in-second-position pattern. Fuss (in press) likewise employs the term "pseudo-V2" to refer to an apparent V2 pattern which does not in fact involve Vin-C, but instead, V-in-T.

47. Embedded V2 is, of course, a phenomenon that features prominently in Romance interrogatives (Adam Ledgeway, p.c.). 


\section{REFERENCES}

Abraham, W. 1993. Null subjects in the history of German: From IP to CP. Lingua 89: 117142.

Adger, D., S. Pintzuk, B. Plunkett and G. Tsoulas (eds). 1999. Specifiers. Minimalist approaches. Oxford: Oxford University Press.

Alexiadou, A. and E. Anagnastopoulou. 1998. Parametrizing Agr: Word order, V-movement and EPP-checking. Natural Language and Linguistic Theory 16: 491-539.

Andersson, L-G. 1975. Form and function of subordinate clauses. Unpublished. $\mathrm{PhD}$ dissertation: University of Gothenburg.

Barnes, M. 1992. Faroese syntax - Achievements, goals and problems. Scripta Islandica 43: $28-43$.

Bayer, J. 1983. COMP in Bavarian syntax. Linguistic Review 3: 209-274.

Bean, M. 1983. The development of word order patterns in Old English. London: Croom Helm.

Beerman, D., D. LeBlanc and H. van Rimesdijk (eds). 1997. Rightward movement. Amsterdam: John Benjamins.

Berman, J. 2000. Topics in the clausal syntax of German. Unpublished $\mathrm{PhD}$ dissertation: University of Stuttgart.

Biberauer, T. 2001. Afrikaans clause structure revisited: A Universal Base Hypothesis account. Unpublished ms: University of Cambridge. 
Bobalijk, J. 1995. Morphosyntax: The syntax of verbal inflection. MIT Working Papers in Linguistic: MIT Department of Linguistics.

Bobalijk, J. and H. Thráinsson. .1998. Two heads aren't always better than one. Syntax 1(1): $37-71$.

Borsely, R. and A. Kathol. 2000. Breton as V2 language. Linguistics 38 (4).

Botha, T., J. van der Merwe and S. Boshoff (eds). Inleiding tot die Afrikaanse taalkunde. Pretoria: Academica.

Burzio, L. 1986. Italian syntax: A Government and Binding approach. Dordrecht: Reidel.

Chomsky, N. 1999. Derivation by phase. Unpublished ms: MIT.

Chomsky, N. 1998. Minimalist inquiries: The framework. Unpublished ms: MIT.

Chomsky, N. 1995. The Minimalist Program. Cambridge, Mass: MIT Press.

Chomsky, N. 1982. Some concepts and consequences of the theory of Government and Binding. Cambridge, Mass: MIT Press.

Cinque, G. 1999. Adverbs and functional heads. Oxford: Oxford University Press.

Conradie, J. 1986. Taalgeskiedenis. Cape Town: Academica.

Conradie, S. 1999. The possibility of parameter resetting: A study on the acquisition of Afrikaans as an L2. Unpublished ms: University of Stellenbosch.

Den Besten, H. 1977/1983. On the interaction of root transformations and lexical deletive rules. In W. Abraham (ed). On the formal syntax of the Westgermania. Amsterdam: John Benjamins. 
Den Besten, H. and G. Webelhuth. 1987. Adjunction and remnant topicalization in the Germanic SOV languages. GLOW Newsletter.

DeHaan, G. and F. Weerman. 1985. Finiteness and verb fronting in Frisian. In H. Haider and M. Prinzhorn (eds). Verb second in Germanic languages. Dordrecht: Foris.

Deumert, A. 1999. Variation and standardization at the Cape (1880 - 1922) - A contribution to Afrikaans historical sociolinguistics. Unpublished $\mathrm{PhD}$ dissertation: University of Cape Town.

Diesing, M. 1990. Verb movement and the subject position in Yiddish. Natural Language and Linguistic Theory 8(1): 41-79.

Donaldson, B. 1993. A grammar of Afrikaans. New York: Mouton de Gruyter.

Du Toit, S. 1898. Die goningin fan Skeba. Salomo syn oue goudfelde in Sambesia. Paarl: D. du Toit and Co. Ltd.

Dunbar, R. 1979. Discourse pragmatics and subordinate clause word order in German: An explanation of related main clause phenomena in German and English clauses. Ann Arbor: UMO.

Falk, C. 1993. Non-referential subjects in the history of Swedish. Uddevalla: MediaPrint.

Feinauer, I. 1987. Sinsvolgorde in Afrikaans. Unpublished PhD dissertation: University of Stellenbosch.

Feinauer, I. 1989. Plasing in Afrikaanse afhanklike sinne. South African Journal of Linguistics 7(1): 30-37. 
Feinauer, I. 1990. Skoon afhanklike sinne in Afrikaanse spreektaal. South African Journal of Linguistics 8(3): 116-120.

Fuss, E. (In press). Residual V2 as the historical origin of the V2 phenomenon. To appear in: Proceedings of ConSole 8.

Giorgi, A. and F. Pianesi. 1997. Tense and aspect. From aemantics to morphosyntax. Oxford: Oxford University Press.

Grewendorf, G. 1988. Aspekte der deutschen Syntax. Tübingen: Gunter Narr.

Haegeman, L. 1998. Embedded verb positions and remnant movement in the West Germanic SOV languages. Unpublished ms: University of Geneva.

Haegeman, L. 1992. Theory and description in generative syntax. A case study in West Flemish. Cambridge: Cambridge University Press.

Haider, H. 1991. Null Subjects and Expletives in Romance and Germanic Languages. In W. Abraham (ed). Issues in Germanic syntax. Berlin: Mouton de Gruyter.

Haider, H. 1986. V-Second in German. In H. Haider and M. Prinzhorn (eds). Verb second phenomena in Germanic languages. Dordrecht: Foris.

Hale, K. and S. Keyser. 1993. On argument structure and the lexical expression of syntactic relations. In K. Hale and S. Keyser (eds). The view from Building 20. Cambridge, Mass: MIT Press.

Helbig, G. and J. Buscha. 1986. Deutsche Grammatik. Leipzig: Verlag Enzyklopädie.

Hendriks, H. and M. Prodeau. 2000. Isn't Dutch a mixture of English and German? On the influence of a second language on the acqusition of a third one. Unpublished ms: Research Centre for English and Applied Linguistics, University of Cambridge. 
Henry, A. 1995. Belfast English and Standard English: Dialect variation and parameter setting. Oxford: Oxford University Press.

Holmberg, A. 2000. V2 languages. Paper presented at the $15^{\text {th }}$ Comparative Germanic Syntax Workshop in Groningen (May 2000) and the Peripheral Positions conference in York (September 2000).

Holmberg, A. and C. Platzack. 1995. The role of inflection in Scandinavian syntax. Oxford: Oxford University Press.

Iatridou, S. and A. Kroch. 1992. The licensing of CP-recursion and its relevance to the Germanic verb-second phenomenon. Working Papers in Scandinavian Syntax 50: 1-24.

Johnson, J. 1990. On the syntax of verbal inflections. Unpublished ms: University of Wisconsin, Madison.

Jonas, D. 1996. Clause structure and verb syntax in Scandinavian and English. Unpublished PhD dissertation: Harvard University.

Kathol. A. 1990. A uniform approach to V2 in German. Proceedings of NELS 20(1): 244-254.

Kathol, A. 1995. Linearization-based German syntax. PhD dissertation: Groningen.

Kayne, R. 1994. The antisymmetry of syntax. Cambridge, Mass: MIT Press.

Koizumi, M. 1993. Object agreement phrases and the split VP-hypothesis. MIT Working Papers in Linguistics 18: 99-148.

Koster, J. 1986 Domains and dynasties. Dordrecht: Foris.

Koster, J. 1975. Dutch as an SOV language. Linguistic Analysis 1: 111-136. 
Langacker, R. 1974. Movement rules in functional sentence perspective. Language 50: 630664.

Larson, R. 1988. On the double object construction. Linguistic Inquiry 19: 335-391.

Lightfoot, D. 1999. The development of language. London: Blackwell.

Lightfoot, D. 1991. Parameter-setting. Cambridge: Cambridge University Press.

Lubbe, J. 1983. Woordvolgordeverandering in die diachroniese ontwikkeling van tale met besondere verwysing na Afrikaans. Bloemfontein: NG Sendingpers.

McCloskey, J. 1992. Adjunction, selection and embedded verb second. Unpublished ms: University of California at Santa Cruz.

Miyagawa, S. 1993. LF-case checking and the minimal link condition. In C. Phillips (ed). Papers on Case and Agreement II: MIT Working Papers in Linguistics 19: 213-254.

Müller, G. 1997. Incomplete category fronting. A derivational approach to remnant movement in German. Dordrecht: Kluwer.

Olivier, E. 1985. Enkele sintaktiese verskynsels in onvoorbereide Afrikaanse spreektaal. Unpublished MA thesis: University of Port Elizabeth.

Oosthuizen, J. 1998. The final nie in Afrikaans negative sentences. Stellenbosch Papers in Linguistics (SPIL) 31: 61-93.

Oosthuizen, J. 1996. Minimalisme en woordordervariasie in Afrikaanse vraagsinne. Stellenbosch Papers in Linguistics (SPIL) Plus 29: 71-98. 
Oosthuizen, J. 1994. 'n Verdere komplement vir COMP. In C. Van der Merwe, H. Waher and J. Hambridge (eds). Rondom Roy. Studies opgedra aan Roy H. Pheiffer. Cape Town: Departement Afrikaans en Nederlands Publications.

Oosthuizen, J. 1985. On the SOV status of Afrikaans. Acta Academica B: 4-22.

Pheiffer, R. 1989. Afrikaans en Standaard-Nederlands. In T. Botha, J. van der Merwe and S. Boshoff (eds). Inleiding tot die Afrikaanse taalkunde. Pretoria: Academica.

Platzack, C. 1985. A survey of generative analyses of the verb second phenomenon in Germanic. Nordic Journal of Linguistics 8: 49-73.

Pollock, J-Y. 1989. Verb movement, UG and the structure of IP. Linguistic Inquiry 12: 365424.

Ponelis, F. 1993. The development of Afrikaans. Frankfurt: Peter Lang.

Raidt, E. 1983. Einführung in Geschichte und Struktur des Afrikaans. Darmstadt: Wissenschaftliche Buchgesellschaft.

Raidt, E. 1971. Afrikaans en sy Europese verlede van Tacitus tot N.P. van Wyk Louw. . Cape Town: Nasou Bpk.

Reinholtz, C. 1989. V-2 in Mainland Scandinavian: Finite verb movement to Agr. Working Papers in Scandinavian Syntax 44: 101-117.

Robbers, K. 1997. Non-finite verbal complements in Afrikaans. A comparative approach. Amsterdam: HIL Dissertations in Linguistics.

Roberts, I. 1993. Verbs and diachronic syntax. Dordrecht: Kluwer. 
Rohrbacher, B. 1994. The Germanic languages and the full paradigm: A theory of V-to-I raising. Unpublished $\mathrm{PhD}$ dissertation: University of Massachusetts at Amherst.

Rögnvaldsson, E. and H. Thráinsson. 1990. On Icelandic word order once more. In J. Maling and A. Zaenen (eds). Modern Icelandic syntax. San Diego: Academic Press.

Santorini, B. 1994. Some similarities and differences between Icelandic and Yiddish. In D. Lightfoot and N. Hornstein (eds). Verb movement. Cambridge: Cambridge University Press.

Schönenberger, M. 2000. The acquisition of verb placement in Lucernese Swiss German. In Friedemann and L. Rizzi (eds). The acquisition of syntax. London: Longman.

Scholtz, J. 1980. Wording en ontwikkeling van Afrikaans. Cape Town: Tafelberg.

Schwartz, B. and S. Vikner. 1989. All verb second clauses are CPs. Working Papers in Scandinavian Syntax 43: 27-49.

Steyn, J. 1977. 'n Paar sintaktiese onvasthede in Afrikaans. Taalfasette 20(3): 25-53.

Stockwell, R. 1984. On the history of the verb-second rule in English. In J. Fisiak (ed). Historical Syntax. Berlin: Mouton de Gruyter.

Travis, L. 1984. Parameters and effects of word order variation. PhD: MIT Working Papers in Linguistics.

Uhmann, S. 1998. Verstellungsvariation in weil-Saetzen: Lexikalische Differenzierung mit grammatischen Folgen. Zeitschrift fuer Sprachwissenschaft 17(1): 92-139.

Ura, H. 2000. Checking theory and grammatical functions in Universal Grammar. Oxford: Oxford University Press. 
Uszkoreit, H. 1987. Word order and constituent structure in German. CSLI Lecture Notes Number 8. Stanford: Centre for the Study of Language and Information (CSLI Publications).

Van Gelderen, E. 1993. The rise of functional categories. Amsterdam: John Benjamins.

Van Kemenade, A. and N. Vincent (eds). 1997. Parameters of morphosyntactic change. Cambridge: Cambridge University Press.

Van Riemsdijk, H. and E. Williams. 1986. Introduction to the theory of grammar. Cambridge, Mass: MIT Press.

Venneman, T. 1974. Topics, subjects and word order: from SXV to SVX via TXV. In J. Anderson and C. Jones (eds). Historical linguistics. Volume I: Syntax, morphology, internal and comparative Reconstruction. Amsterdam: North Holland.

Vikner, S. 1995. Verb movement and expletive subjects in the Germanic languages. Oxford: Oxford University Press.

Vikner, S. and B. Schwartz. 1996. The verb always leaves IP in V2 clauses. In: A. Belletti and L. Rizzi (eds). Parameters and functional heads. Essays in comparative syntax. Oxford: Oxford University Press.

Vriends, E. 1998. Morphosyntax of verb movement and Afrikaans verbal constructions. Stellenbosch Papers in Linguistics (SPIL) 31: 95-124.

Waher, H. 1982. The position of the finite verb in Afrikaans. Stellenbosch Papers in Linguistics (SPIL) 8: 51-78.

Webelhuth, G. 1992. Principles and parameters of syntactic saturation. Oxford: Oxford University Press. 
Weerman, F. 1989. The V-2 conspiracy - a synchronic and diachronic analysis of verbal positions in Germanic languages. Dordrecht: Foris Publications.

Willis, D. 1996. The loss of verb second in Welsh: A study of syntactic change. PhD dissertation: University of Oxford.

Zwart, J. 1993. Dutch syntax. A Minimalist approach. PhD dissertation: University of Groningen.

Zwart, J. 1994. Dutch is head initial. The Linguistic Review 11: 377-406.

Zwart, J. 1997a. Morphosyntax of verb movement. A Minimalist approach to the syntax of Dutch. Dordrecht: Kluwer.

Zwart, J. 1997b. The Germanic SOV languages and the Universal Base Hypothesis. In L. Haegeman (ed). The new comparative syntax. London: Longman. 